\title{
The Impact of Tumor and Lymph Node Characteristics on Disease Free Survival in Squamous Cell Vulvar Cancer
}

\author{
Derya A. CIRIK ${ }^{1}$, Alper KARALOK ${ }^{1}$, Isin UREYEN ${ }^{1}$, Osman TURKMEN ${ }^{1}$, Tolga TASCI ${ }^{1}$, \\ M. Ali NARIN ${ }^{1}$, Mehmet F. KOSE ${ }^{2}$, Nurettin BORAN ${ }^{1}$, Taner TURAN ${ }^{1}$, Gokhan TULUNAY ${ }^{1}$ \\ ${ }^{1}$ Etlik Zübeyde Hanım Women's Health Training and Research Hospital, \\ Department of Gynecologic Oncology, Ankara \\ ${ }^{2}$ Medipol University School of Medicine, Department of Obstetrics and Gynecology, Istanbul, TURKEY
}

\begin{abstract}
We aimed to determine the prognostic significance of tumor and lymph node (LN) characteristics on disease free survival (DFS) in patients who underwent surgery for squamous cell vulvar carcinoma. A total of 94 patients who underwent vulvar surgery and groin dissection were included. The impact of clinicopathologic variables such as age, body mass index, tumor size, tumor depth, total and metastatic lymph node number on DFS were assessed. The estimates of survival were determined with Kaplan-Meier and log rank analysis. In the univariate analysis; age, body mass index, tumor size, tumor location, total LN number, metastatic LN number and adjuvant therapy did not have impact on DFS. The median number of removed LNs was 21. Although removal of higher number of lymph nodes did not improved the DFS, patients who had $\leq 3$ metastatic LNs had better 2-year DFS rate compared to those with $>3$ metastatic LNs (71.8\% vs $40.0 \%$; $p=0.042$, respectively). In the multivariate analysis, both the depth of tumor invasion and LN involvement were the independent predictors of DFS. Additionally, in stage III disease, patients receiving adjuvant therapy had significantly less locoregional recurrence compared to those who did not receive. The presence of LN metastasis and increased tumor depth (> $3 \mathrm{~mm}$ ) are poor prognostic factors for DFS in squamous cell vulvar cancer. Although the number of lymph nodes removed was not correlated with DFS, patients who had $\leq 3$ metastatic LNs had better DFS compared to those with $>3$ LNs.
\end{abstract}

Keywords: Vulvar cancer, lymph node, disease free survival, recurrence

ÖZET

Skuamöz Hücreli Vulva Kanserinde Tümör ve Lenf Nodu Özelliklerinin Hastalıksız Sağkalıma Etkisi

Bu çalışmada, skuamöz hücreli vulva kanseri için cerrahi yapılan hastalarda tümör ve lenf nodu (LN) Özelliklerinin hastalıksız sağkalıma (DFS) etkisini incelemek amaçlandı. Vulvar cerrahi ve lenf nodu diseksiyonu yapılan toplam 94 hasta çalışmaya dahil edildi. Yaş, vücut kitle indeksi, tümör boyutu, tümör derinliği, total ve metastatik LN sayısı gibi klinikopatolojik değişkenlerin DFS'ye etkisi araştırıldı. Sağkalım analizleri ise Kaplan-Meier ve log rank analizi ile yapıldı. Univaryant analizine göre, yaş, vücut kitle indeksi, tümör boyutu ve yeri, toplam LN sayısı, metastatik LN sayısı ve adjuvan tedavi DFS üzerine etkili bulunmadı. Ortalama olarak 21 tane LN çıkarılı. Ortalamadan fazla lenf nodu çıkarılması DFS üzerine etkili olmasa da, 3 ve daha az metastatik LN çıkarılan hastalar, 3'den fazla metastatik LN çıkarılanlardan daha iyi 2-yllık-DFS'ye sahip bulundu (sırasıyla, \%71.8 ve \%40.0; $p=0.042$ ). Multivaryant analizde, hem tümör derinliği hem de LN tutulumu DFS'nin bağımsız prediktörleri idi. Ek olarak, evre III hastalıkta, adjuvan tedavi alan hastalar almayanlara göre daha az lokal (perineal ve kasık) nüksüne sahip idi. Lenf nodu metastazı ve artmış tümör derinliği (> 3 mm), skuamöz hücreli vulva kanseri için kötü prognostic faktörlerdir. Çıkarılan LN sayısı ile 2-yllık-DFS korele olmasa da evre III hastalarda, 3 ve daha az metastatik LN çıkarılan hastalarda 3'den fazla LN çıkarılanlara göre daha iyi DFS izlenmektedir.

Anahtar Kelimeler: Vulva kanseri, Lenf nodu, Hastalıksız sağkalım, Nüks 


\section{INTRODUCTION}

Squamous cell vulvar carcinoma (vSCC) is the most common histologic type of vulvar cancer and surgery is the essential step for both staging and treatment. Although new methods for lymph node dissection were introduced, the widely used surgical treatment includes tumor resection with free margins and inguinofemoral lymph node dissection. ${ }^{1-3}$ Since two decades, involvement of groin lymph nodes (LNs) has been reported as the most important prognostic factor for survival. ${ }^{4}$ The age, tumor size, tumor location, stage, depth of invasion, the LN status and free margins were suggested as the possible predictive factors of recurrence..$^{5-8}$ However, these risk factors were determined relying on the data generally based on small studies for vSCC. Nearly half of recurrences occur within first two years and when diagnosed, patients with locoregional recurrences have usually the chance of surgical treatment and good prognosis. ${ }^{9}, 10$ Therefore, the clarification of the surgico-pathological factors that facilitate the recurrence were crutial for the patients with vSCC.

In the present study, we assessed the prognostic significance of surgico-pathological variables and LN profile on DFS in patients who underwent surgery for vSCC.

\section{PATIENTS AND METHODS}

A total of 136 patients with vSCC treated at the Gynecologic Oncology Department of our institution between December 1991 and August 2013. Patients with depth of invasion $<1 \mathrm{~mm}(\mathrm{n}=7)$, with advanced stage disease treated with primary chemo- or radiotherapy (RT) $(n=22)$, who admitted with recurrence $(n=1)$, treated without surgery due to the advanced interstitial lung disease ( $n=$ $1)$ and with non-squamous histology $(n=11)$ were excluded. Remaining 94 patients who underwent surgery for vSCC were eligible for further analysis. This study confirmed the principles outlined in Helsinki Declaration.

After local ethical committee approval, the clinical data and pathologic data were collected from the computerized database of the department. A recurrence was defined as the new appearance of a tumor after surgery and at least a 3 months disease free period. DFS was defined as the time from the date of the surgery to the date of recurrence or last follow-up. Recurrence was diagnosed by clinical examination, biopsy and radiologic imaging. According to our protocols; vulvar tumor less than $2 \mathrm{~cm}$ and less than $1 \mathrm{~mm}$ invasion was resected with at least $1 \mathrm{~cm}$ tumor free margin via wide local excision, other tumors were usually resected by radical vulvectomy. All patients scheduled to have bilateral inguinofemoral lymphadenectomy. However one patient had only unilateral lymphadenectomy due to an orthopedic disease of hip joint and limitation of abduction. Groin dissections were performed with the triple separate incision method. Adjuvant perineal RT was performed when tumor free margin was less than $8 \mathrm{~mm}$ and tumor depth $>5 \mathrm{~mm}$ or when tumor spread into the urethra and anal region. Adjuvant treatment of groins and pelvis was performed via pelvic RT with/without chemotherapy when at least one LN was tumor positive or when tumor size exceeded $4 \mathrm{~cm}$ length. Radiotherapy field included the inguinofemoral lymph nodes and at least the lower pelvic nodes. Over 5 weeks, 45 Gy in 25 fractions were given. If there were multiple lymph nodes, up to 60 Gy was given to a reduced volume.

None of the patients took adjuvant chemotherapy. However, adjuvant chemoradiotherapy was given to patients with high risk factors (high number of $\mathrm{LN}$, bigger tumor size, etc) according to the doctors' preferences and experience.

Because most of the recurrence occur in vulva and groin, the diagnosis were usually made with clinical examination, biopsy and radiologic imaging when required. When the recurrence was diagnosed the lower and upper abdominal $\mathrm{CT}$ and lung $\mathrm{X}$-ray were performed. Especially in recent years, we also routinely do PET-CT for evaluation.

Variables were analyzed by using SPSS software (version 15.0 for Windows, Chicago, IL, USA). For descriptive analyses, categorical variables were defined as numbers and percentages, and numeric variables were defined as mean or median. Chi-square and student t-test were used as appropriate to test the differences between two groups. The estimates of survival were determined using the Kaplan Meier analysis. The survival analysis of categorical variables were examined by log rank 


\begin{tabular}{|ll|}
\hline $\begin{array}{l}\text { Table 1. Clinical and pathological characteristics of patients } \\
\text { with vulvar cancer }\end{array}$ & $\mathbf{n}$ (\%) \\
\hline Parameters & \\
\hline $\begin{array}{l}\text { Tumor size [mm] } \\
<10\end{array}$ & $10(10.6 \%)$ \\
$10-29$ & $48(51.1 \%)$ \\
$\geq 30$ & $36(38.3 \%)$ \\
Tumor location & \\
$\quad$ Midline & $45(47.9 \%)$ \\
Right side & $18(19.1 \%)$ \\
Left side & $31(33.0 \%)$ \\
Depth of invasion [mm] & \\
$\quad \leq 3$ & $38(40.4 \%)$ \\
$>3$ & $36(38.3 \%)$ \\
Not reported & $20(21.3)$ \\
Adjuvant therapy & \\
No therapy & $51(54.3 \%)$ \\
Radiotherapy & $34(36.2 \%)$ \\
Radiotherapy + Chemotherapy & $9(9.6 \%)$ \\
\hline
\end{tabular}

test and the continuous variables were examined by univariant cox propotional hazard model. The statistical power of the variables were defined by using binary logistic regression and variables with a $\mathrm{p}$ value of less than 0.05 analyzed in the multivariate analysis.

\section{RESULTS}

\section{Clinical and Pathological Data}

Median age and body mass index (BMI) of the patients were 64.5 years (range: $37-87$ years) and $28.4 \mathrm{~kg} / \mathrm{m}^{2}$ (range: $18-48 \mathrm{~kg} / \mathrm{m}^{2}$ ), respectively. Details of patients' characteristics were listed in Table 1. All tumors were primarily confined to the vulva and the median tumor size was $20 \mathrm{~mm}$ (range: $2-80$ $\mathrm{mm}$ ) in diameter and median tumor invasion was 3 $\mathrm{mm}$ (range: 1-25 mm) in depth. Seventy-nine patients $(84 \%)$ had radical vulvectomy, $10(10.6 \%)$ had wide local excision and $5(5.3 \%)$ had hemivulvectomy. Except for one who had unilateral groin dissection, all had bilateral groin dissection, Of all, 43 (45.7\%) had LN metastasis; 10 had unilateral and 33 had bilateral LN metastasis in groin. The median number of resected LNs was 21 . The number of LNs was $\leq 10$ in 8 patients $(8.5 \%)$ and $\leq 15$ in 19 patients (20.2\%). All patients underwent lymphadenectomy and patients were divided into two categories according to the International Federation of Gynecology and Obstetrics (FIGO) staging system. The first group included 51 patients who had no LN metastasis (Stage I and II), and the second group included 43 patients who had LN metastasis (Stage III). There was no patient with stage IV disease.

\begin{tabular}{|c|c|c|c|}
\hline \multirow[t]{2}{*}{ Parameter } & \multicolumn{3}{|c|}{ Sites of recurrence } \\
\hline & Perineal, n (\%) & Inguinal, $\mathbf{n}(\%)$ & Distant, n (\%) \\
\hline \multicolumn{4}{|c|}{ Lymph node metastasis (FIGO Stage) } \\
\hline Negative (Stage I-II) & $8(61.5)$ & $4(30.8)$ & $1(7.7)$ \\
\hline Positive (Stage III) & $11(57.8)$ & $6(37.5)$ & $2(10.5)$ \\
\hline $\mathrm{P}$ & 0.307 & & \\
\hline \multicolumn{4}{|l|}{ Localization of tumor } \\
\hline Midline & $8(50)$ & $7(43.7)$ & $1(6.3)$ \\
\hline Lateral & $11(68.7)$ & $3(18.7)$ & $2(12.6)$ \\
\hline $\mathrm{P}$ & 0.829 & & \\
\hline \multicolumn{4}{|l|}{ Adjuvant radiotherapy } \\
\hline Not received & $12(60)$ & 7 (35.0) & 1 (5) \\
\hline Received & 7 (58.3) & $3(25)$ & $2(16.7)$ \\
\hline$P$ & 0.281 & & \\
\hline
\end{tabular}


International Journal of Hematology and Oncology

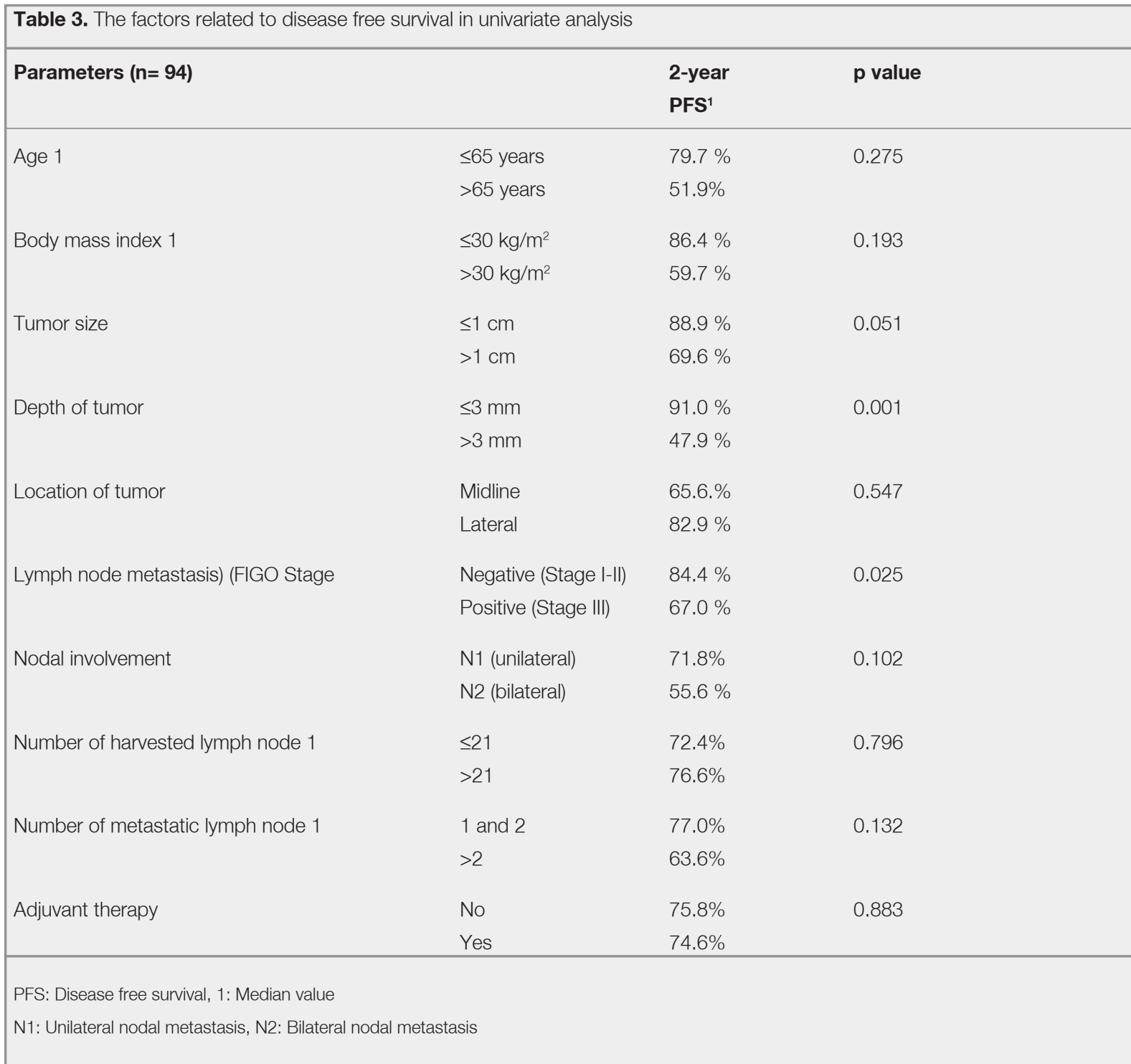

\section{Patterns of First Recurrence}

The median follow-up was 24 months (range: 3-158 months). The estimated 5-year and 10-year DFS were $41 \%$ and $28 \%$, respectively. During the follow-up, 32 (34\%) patients had the first recurrence after a median interval of 23.5 months (range: 6-120 months). The distribution of relapses by location was perineal recurrence in $19(59.4 \%)$ patients, groin recurrence in $10(31.2 \%)$, and distant organ recurrence in $3(9.4 \%)$ patients. Although total recurrence rate was higher in patients with Stage III disease than in those with Stage I\&II disease, the difference did not reach statistical significance ( $44.2 \%$ vs $25.5 \%, p=0.08$, respectively). The sites of recurrences according to the stage were shown in Table 2. The sites of recurrence were also similar in both groups of patients with LN positivity (Stage III) and negativity (Stage I\&II) $(\mathrm{p}=0.307)$.

Adjuvant Therapy and Locoregional Recurrence

Although LN positivity is an indication for adjuvant therapy in our clinical protocols, 15 (34.9\%) of 43 patients with stage III disease did not receive adjuvant therapy after primary surgery due to poor performance status or patients' preference. Of the patients with Stage III disease, 11 had perineal and 6 had groin recurrences. In stage III disease, patients receiving adjuvant therapy had significantly less locoregional recurrences (perineal and groin) compared to those who did not receive $(n=7 / 29$; $24.1 \%$ vs $n=10 / 15 ; 66.7 \%, p=0.006)$. Only 2 of 


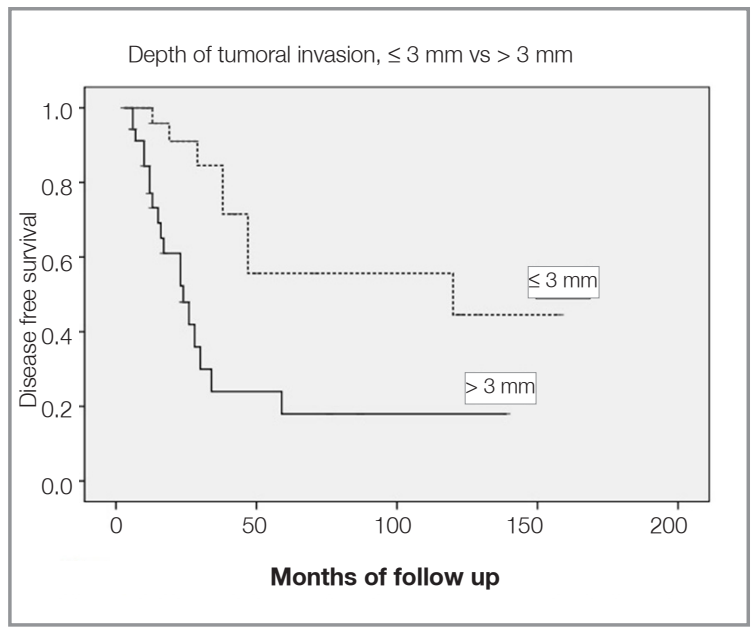

Figure 1. Disease free survival according to the depth of tumor invasion

these 6 patients with groin recurrence received adjuvant RT and 5 of 11 patients with locoregional recurrences received adjuvant therapy (4 RT and 1 had concomitant chemo-RT after primary surgery).

Of the 51 patients with stage I-II disease, 15 received radiation therapy to perineum. In stage I-II disease, patients receiving adjuvant therapy had similar locoregional recurrence rates compared to those who did not receive $(n=3 / 14 ; 21.4 \%$ vs $n=$ $9 / 36 ; 24 \%, p=1.0$ ). A total of 4 groin and 8 perineal recurrences developed in patients with stage I-II disease. Of the 4 patients with groin metastasis, only 1 had stage II disease with urethral involvement and had received vulvar RT. Of the 8 patients with perineal recurrences, only 2 had received vulvar RT after surgery.

\section{Clinicopathologic Factors and DFS}

In the univariate analysis, depth of tumor invasion and LN status were found to be associated with DFS in vSCC (Table 3). The tumor size was also tending

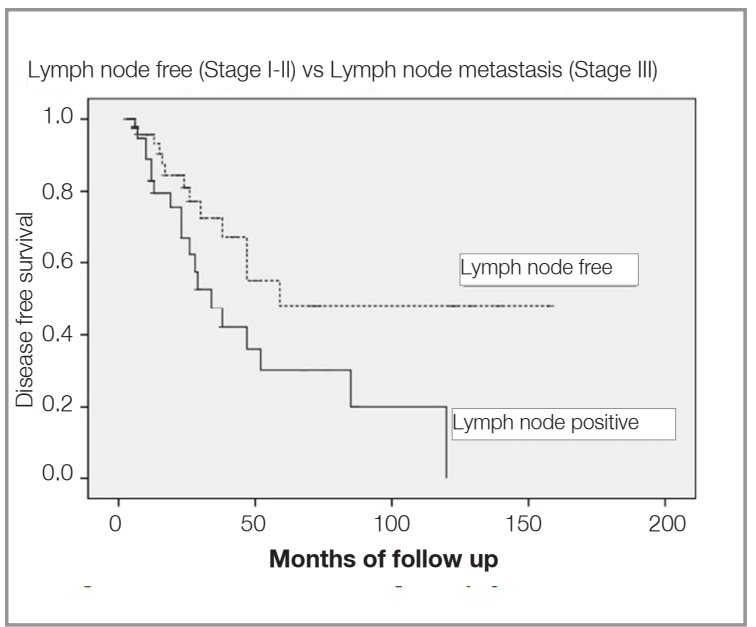

Figure 1. Disease free survival according to the lymph node status

to be associated with DFS. On the other hand, the number of removed LNs was not correlated with improvement in DFS. The 2-year DFS was $72.4 \%$ for patients whose $\leq 21$ LNs were removed and $76.6 \%$ for those whose $>21 \mathrm{LNs}$ were removed $(\mathrm{p}=$ 0.796). Median number of metastatic LN in Stage III disease was 2 in the current study. Patients who had $\leq 2$ metastatic LNs had similar 2-year DFS rate compared to those with $>2$ metastatic LNs $(71.4 \%$ vs $63.6 \% ; \mathrm{p}=0.38$, respectively). On the other hand, when the patients were grouped according to the number of metastatic lymph nodes; patients who had $\leq 3$ metastatic lymph nodes had better 2-year DFS compared to those who had $>3$ metastatic lymph nodes (71.8\% vs $40.0 \%$; $\mathrm{p}=0.042$ ).

In both groups of patients who received and did not receive adjuvant therapy, 2-year DFS was also similar for patients with $\leq 2$ metastatic LNs and with more metastatic LNs $(79.3 \%$ vs $66.7 \%$; $\mathrm{p}=$ 0.289 and $75.4 \%$ vs $66.7 \%$; $p=0.301$, respectively). Two-year DFS was $55.6 \%$ for patients with

\begin{tabular}{|llll|}
\hline \multicolumn{4}{|l|}{ Tablo 4. Multivariate analysis of selected clinicopathological variables regarding disease free survival } \\
\hline Parameter & p value & HR & $\mathbf{9 5 \% ~} \mathbf{~ I ~}$ \\
\hline Tumor size ( $\leq 10 \mathrm{~mm}$ vs $>10 \mathrm{~mm})$ & 0.093 & 2.928 & $0.835-10.267$ \\
Depth of tumor $(\leq 3 \mathrm{~mm}$ vs $>3 \mathrm{~mm})$ & 0.016 & 3.022 & $1.227-7.442$ \\
FIGO stage (stage 1 and 2 vs stage 3) & 0.049 & 2.243 & $1.003-5.019$ \\
Body Mass Index $\left(\leq 30 \mathrm{~kg} / \mathrm{m}^{2}\right.$ vs $\left.>30 \mathrm{~kg} / \mathrm{m}^{2}\right)$ & 0.056 & 0.401 & $0.157-1.025$ \\
\hline
\end{tabular}


bilateral positive LNs while patients with unilateral positive LNs had a DFS of $71.8 \%(\mathrm{p}=0.102)$. Among 32 patient who had recurrence, 10 were died due to their disease during follow-up. Twoyear overall survival was estimated as $91.4 \%$ for the entire cohort.

In the multivariate analysis, depth of tumor invasion and LN involvement (stage I-II vs III) were found as the independent prognostic factors for DFS (Figure 1 and 2). Patients with stage III disease were 2.24 times more prone for developing recurrence than those with stage I and II disease. Patients with $>3 \mathrm{~mm}$ depth of invasion had 3.022 times more risk for regarding DFS compared to those who had less invasion (Table 4).

\section{DISCUSSION}

In the current study, a relatively large cohort ( $\mathrm{n}=$ 94) who underwent lymphadenectomy for vSCC were analyzed. All patients underwent primary surgical treatment with tumor resection and lymphadenectomy. The estimated 5-year and 10-year DFS were $41 \%$ and $28 \%$, respectively and the recurrence rate was $34 \%$ (n: 32/94). In accordance to our results, Maggino et al. reported 37.2\% recurrence within 502 patients in their study, the largest series in the literature. ${ }^{10}$ Iacoponi et al. reported higher recurrence rate $(43.6 \%)$ in a study of 87 patients with a median age of 73 years and median tumor size of $35.4 \mathrm{~mm} .{ }^{7}$ Higher incidence of recurrence might be attributed to the presence of older patients and bigger tumors in that study. On the other hand, Woelber et al. reported the recurrence rate as only $13.6 \%$ in a study of 109 patients $56 \%$ of whom had tumor less $\leq 2 \mathrm{~cm}$ in greatest diameter. ${ }^{5}$ The lower incidence of recurrence might be explained by the inclusion of the stage $1 \mathrm{~A}$ disease and the presence of higher percentage of T1 tumor ( $\leq 2 \mathrm{~cm}$ in greatest diameter, confined to the vulva) in these patients. In the current study, the perineal recurrence was the most common recurrence and seen in $20.2 \%$ of patients. This rate was also comparable with the rates $(18.8 \%$ to $26.2 \%)$ in the other series. ${ }^{5,6}$ The incidence of groin recurrence was $10.6 \%$ in the current study and similar to the rate of $10.1 \%$ groin recurrence in a study of 158 patients who were treated with bilateral lymphadenectomy by Baiocchi et al. ${ }^{11}$
There are studies investigating the predictive factors for DFS or overall survival for vSCC, but they often had heterogeneous group of patients with non-squamous cell cancer or patients having different treatment modalities. ${ }^{7-12,13-15}$ The results of this study also verified that LN involvement was clearly confirmed as being the most important prognostic factor for both DFS. In the multivariate analysis, LN involvement was the independent prognostic factor regarding DFS in the current study. Woelber et al. stated that patients with unilateral and bilateral metastasis were estimated to have 5.1 and 16.9 times more recurrence risk compared to those with negative LNs, respectively. ${ }^{5}$ Similarly, Iacoponi et al. also reported that bilateral $\mathrm{LN}$ metastasis was also tend to be associated with higher locoregional recurrences rate compared to unilateral metastasis. ${ }^{7}$

Up to date, the number of optimal lymph node number that should be removed is not clarified yet. Few authors investigated the prognostic significance of the number of removed LNs in vulvar cancer and conflicting results were reported..$^{10,12-16}$ In a large population database trial of 1030 patients, Courtney-Brooks et al. reported higher disease specific survival with removal of $\geq 10 \mathrm{LN}$ in patients with $\mathrm{LN}$ negative vulvar cancer. ${ }^{14}$ Similarly, a recent trial also reported an improvement on DFS with removal of $\geq 15$ nodes at bilateral lymphadenectomy. ${ }^{16}$

Contrary to this, Baiocchi et al. did not find any survival benefit by removing more LNs $(\geq 12)$ in patients with Stage I\&II disease. ${ }^{11}$ However, they also analyzed the patients with Stage III disease and found significantly higher PFS in patients who had removal of higher number LN; 2-year PFS for patients with removal of $<12 \mathrm{LN}$ and $\geq 12 \mathrm{LNs}$ were $20.8 \%$ vs $52.8 \%$, respectively $(\mathrm{p}=0.003)$. In that study, only $7.6 \%$ of 158 patients received adjuvant therapy. On the other hand, median number of harvested LNs was 21 in the current study and removing higher LN counts also did not improved the DFS in the entire cohort. In our study $45.7 \%$ of patients had received adjuvant therapy. This result could be explained by the more effective local control of tumor with the use of more frequent adjuvant therapy in the current study. 
In a recent study of Vismanathan et al., LN involvement and positive margins $(<1 \mathrm{~cm}$ with the edge of tumor) but not depth of invasion were found as the clinical predictors of recurrence. ${ }^{17}$ That study specifically evaluated the relation between adjuvant RT and perineal recurrence and found significantly lower risk of perineal recurrence with the use of RT. On the other hand, patients with $>3 \mathrm{~mm}$ depth of invasion were estimated to have 3.022 times more shorter DFS compared to those who had less invasion in the current study.

Locoregional recurrences usually occur by direct tumoral spread or lymphatic embolization to regional LNs and they were attributed to the defects either in the surgical treatment or in the local control by the adjuvant therapy. In a recent study, prognostic factors for developing locoregional recurrences were investigated in 78 patients and only receiving adjuvant therapy was found to reduce the perineal and groin recurrence significantly. ${ }^{7} \mathrm{Al}-$ though, distinct criteria for indication of adjuvant therapy following primary tumor resection are still under debate, survival advantage of adjuvant RT on patients with two or more metastatic LNs was confirmed in the literature. ${ }^{18}$ On the other hand, the status of patients who had one intracapsular LN involvement is controversial. In a recent study, Fons et al. could not show a benefit of adjuvant therapy in patients with a single metastatic $\mathrm{LN}$ regarding the DFS. ${ }^{19}$ However, the negative effect of single LN involvement on DFS was also shown by other researchers. ${ }^{13,20}$ According to our clinical protocols, one metastatic LN was sufficient for the indication of adjuvant therapy. All patients with positive LNs were candidates for adjuvant therapy in the current study. The patients with stage III disease who received adjuvant therapy had significantly less perineal and groin recurrence compared to those who did not receive $(\mathrm{p}=0.006)$.

In the present study, metastatic LN number was not related with DFS in the entire cohort. Patients with $\leq 2$ metastatic LN had similar DFS to those who had $>2$ metastatic LNs.

However, patients who had $\leq 3$ metastatic LNs had better DFS compared to those who had $>3$ metastatic nodes. Our results were consistent with a recent trial of Panici et $\mathrm{al}^{16}$ that stated that patients who had $>3$ metastatic LN had worse OS and DFS compared to those who have lesser LNs. In the present study, the impact of metastatic LN on the DFS was analyzed in patients receiving and not receiving adjuvant therapy after subgroup analysis. In both groups of patients, number of metastatic LNs had no association with DFS ( $\mathrm{p}=0.289$ and $\mathrm{p}=0.301$, respectively). In a study of 157 patients, Woelber et al. investigated the prognostic role of $\mathrm{LN}$ metastasis on recurrence. Although the number of metastatic LNs was not also shown to have impact on DFS in patients who received adjuvant therapy, metastatic LN number had significant impact on prognosis in patients who did not receive adjuvant therapy in that study. ${ }^{20}$

Strengths of this study include the relatively high number of patients with a rare disease diagnosed in a single center. Limitations were the retrospective nature of the study and the inclusion of patients diagnosed within 2 decades.

In conclusion, LN metastasis and tumor with $>3$ $\mathrm{mm}$ depth of invasion were independent prognostic factors for DFS in patients with vSCC. Although LN metastasis is very crucial for recurrence, removing more LNs did not improve DFS. Although there is debate on the indications of adjuvant therapy for vSCC, receiving adjuvant RT in even one positive $\mathrm{LN}$ may decrease the risk of the recurrence.

\section{REFERENCES}

1. Siegel R, Ward E, Brawley O, Jemal A. Cancer statistics, 2011: The impact of eliminating socioeconomic and racial disparities on premature cancer deaths. CA Cancer J Clin 61: 212-236, 2011.

2. Hacker NF, Berek JS, Lagasse LD, et al. Individualization of treatment for stage I squamous cell vulvar carcinoma. Obstet Gynecol 63:155-162, 1984.

3. Wu Q, Zhao YB, Sun ZH, et al. Clinical application of endoscopic inguinal lymph node resection after lipolysis and liposuction forvulvar cancer. Asian Pac J Cancer Prev 14: 71217126, 2013.

4. Homesley HD, Bundy BN, Sedlis A, et al. Assessment of current International Federation of Gynecology and Obstetrics staging of vulvar carcinoma relative to factors for survival (a GOG group). Am J Obstet Gynecol 164: 997-1003, 1991.

5. Woelber L, Manher S, Voelker K, et al. Clinicopathological prognostic factors and patterns of recurrence in vulvar cancer. Anticancer Research 29: 545-552, 2009. 
6. Martinez-Palones JM, Perez-Benavente MA, Gil-Moreno A, et al. Comparison of recurrence after vulvectomy and lymphadenectomy with and without sentinel node biopsy in early stage vulvar cancer. Gynecol Oncol 103: 865-870, 2006.

7. lacoponi S, Zapardiel I, Diestro MD, et al. Prognostic factors associated with local recurrence in squamous cell carcinoma of the vulva. J Gynecol Oncol 24: 242-248, 2013.

8. Stankevica J, Macuks R, Baidekalna I, Donina S. Midline involvement as a risk factor for vulvar cancer recurrence. Asian Pac J Cancer Prev 13: 5237-5240, 2012.

9. Onnis A, Marchetti M, Maggino T. Carcinoma of the vulva: Critical analysis of survival and treatment of recurrences. Eur J Gyneacol Oncol 13: 480-485, 1992.

10. Maggino $T$, Landoni $F$, Sartori $E$, et al. Patterns of recurrence in patients with squamous cell cancer of the vulva. A multicenter CTF Study. Cancer 89: 116-122, 2000.

11. Baiocchi G, Cestari FM, Rocha RM, et al. Does the count after inguinofemoral lymphadenectomy in vulvar cancer correlate with outcome? Eur J Surg Oncol 39: 339-343, 2013.

12. Lataifeh 11, Nascimento MC, Nicklin JL, et al. Patterns of recurrence and disease-free survival in advanced squamous cell carcinoma of the vulva. Gynecol Oncol 95: 701-705, 2004.

13. Oonk MH, de Hullu JA, van der Zee AG. Current controversies in the management of patients with early-stage vulvar cancer. Curr Opin Oncol 22: 481-486, 2010.

14. Courtney-Brooks M, Sukumvanich P, Beriwal S, et al. Does the number of nodes removed impact survival in vulvar cancer patients with node-negative disease? Gynecol Oncol 117: 308$311,2010$.

15. Le T, Elsugi R, Hopkins L, et al. The definition of optimal inguinal femoral nodal dissection in the management of vulva squamous cell carcinoma. Ann Surg Oncol 14: 2128-2132, 2007.
16. Panici PB, Tomao F, Domenici L, et al. Prognostic role of inguinal lymphadenectomy in vulvar squamous carcinoma: younger and older patients should be equally treated. A prospective study and literature review. Gynecol Oncol 137: 373-379, 2015.

17. Viswanathan AN, Pinto AP, Schultz D, et al. Relationship of margin status and radiation dose to recurrence in post-operative vulvar carcinoma. Gynecol Oncol 130: 545-549, 2013.

18. Mahner S1, Trillsch F, Kock L, et al. Adjuvant therapy in nodepositive vulvar cancer. Expert Rev Anticancer Ther 13: 839844, 2013.

19. Fons G, Groenen SMA, Oonk MHM, et al. Adjuvant radiotherapy in patients with vulvar cancer and one intra capsular LN metastasis is not beneficial. Gynecol Oncol 114: 343-345, 2009.

20. Woelber L, Eulenburg C, Choschzick M, et al. Prognostic role of $L N$ metastases in vulvar cancer and implications for adjuvant treatment. Int J Gynecol Cancer 22: 503-508, 2012.

\section{Correspondence}

Dr. Derya Akdag CiRiK

Yeni Etlik Caddesi No: 55

06010 Kecioren/ANKARA

Tel: (+90-312) 5674000

Fax: (+90-312) 3238191

e-mail: deryaakdag@yahoo.com 